\title{
WRITING FROM MEMORY: HISTORY, STORIES AND NARRATIVE VOICES IN IN THE TIME OF THE BUTTERFLIES BY JULIA ÁLVAREZ
}

\section{Manuel F. Medina}

University of Louisville

\section{Abstract:}

Julia Álvarez (Dominican Republic, 1951) and her family left the Dominican Republic in 1960 to escape the persecution of Rafael Leónidas Trujillo's dictatorship, which ruled the country with terror from 1930 to 1961 . Her father had gotten involved with clandestine forces that attempted to overthrow the dictator. Precisely the opposition to Trujillo's dictatorship constitutes the referent of her second novel, In the Time of the Butterflies (1994), which deals with the life of the four Mirabal sisters, Minerva, María Teresa (Mate), Patria, and Dedé. My article, using a theoritical framework based mostly in the works of Foucault, Hayden White and Linda Hutcheon poses that In the Time of the Butterflies revises the official history of the Mirabal sisters and their subsequent murder by providing a more humanized version of their own stories in order to divide the truth of the myth created about the three sisters. The novel shows their development as characters as we follow them in different stages of their lives while the shadow of dictator Trujillo's looms large encompassing every aspect of their and everybody's existence. Lastly, I argue that Julia Álvarez's position of being born Dominican, but acculturated as an 
American, allows her to observe and present the text from a unique view and perspective. She travels to the places of the facts to research the sisters' story and to get to know the archive that includes not only the official versions, but also the most credible mythicized oral accounts provided by Dedé, the Mirabals' other relatives, neighbors and the like. The novel's greatest merit derives from its attempt to revise history from memory, the collective memory whose voices Álvarez masterfully reproduces and therefore perpetuates in the pages of the book.

Keywords: Memory, History, Narrative, Julia Álvarez.

The narrative work of Julia Álvarez (Dominican Republic, 1951) has received great critical acclaim from her reading audience. Her books, in the original English and the respective Spanish translations have become editorial successes. In general, we find two trends in Julia Álvarez's narrative: issues of identity forged by cultural adaptation and assimilation and the presence and use of historical events and characters as her fiction's point of departure. Julia Álvarez's novels explore topics and referents that she extensively knows or has carefully researched. For instance, How the Garcia Girls Lost Their Accents (1991) explores the cultural adaptation of four Dominican sisters who experience their adolescence in New York, a world different from that which they were used to in their childhood. The plot recalls the personal experience of Álvarez who, at the age of 10, emigrated from the Dominican Republic to Queens, New York, in 1960 in company of her four sisters (Bing). The Dominican writer reintroduced the story of How the Garcia Girls Lost Their Accents in her third novel Yo! (1997), by further developing the character of Yolanda who had already appeared as a one of the sisters in her opera prima. The main narrator uses the voices of sixteen different narrators in an attempt to deliver a more complete and unbiased version of Yolanda. The reader realizes that besides the normal difficulties that every migrant faces, Yolanda must also learn to live within the borders of the two cultures to which she belongs. Regarding her other trend, the one related to history and historical fiction, we know that Julia Álvarez extensively researches the topics that she develops. For example, Álvarez studied the archives 
of the National Library of Havana before sitting down to write In the Name of Salomé(2000), a novel based upon the lives of Salomé Urena, a famous nineteenth century Dominican poet, and her daughter Camila, who was born in Cuba and actively participated in Castro's subversion.

The opposition to Trujillo's dictatorship, an event that adversely touched her personal life, constitutes the referent of her second novel, In the Time of the Butterflies (1994). The story uses three sections and an epilogue to retell the life of the four Mirabal sisters, Minerva, María Teresa (Mate), Patria, and Dedé. Each sister has the opportunity to express herself and to help in the making of her own character; the novel shows them at different stages throughout their lives. Meanwhile the shadow of dictator Trujillo and its almighty power emanates and surrounds all and everything. The first section depicts them facing their innate problems of childhood and adolescence. The consecutive sections portray them as youths, mothers, wives, and eventually, as defenders of their country against the corrupt government. Each division begins with the intervention of Dedé, the only one who did not perish together with the other three and who provides her version of events, analyzing them under the filter made along thirty-three years of memories and meditations. Dedé narrates the past as well as her immediate present and tells about her life with and without her sisters. In the epilogue, the novel intersperses Dedé's meditations with the narration of the Mirabal sisters' death, retold by different existing versions of the massacre.

In the Time of the Butterflies fully conscious of its historical context, role and ideological implications warns us about it from the onset. One of the initial pages refers us to the end of the book, to a section titled " $A$ Postscript" that explores the role of several historical texts in the novel's gestation process: "This work of fiction is based on historical facts referred to in the author's Postscript on pages 323-324". Álvarez explains that historical texts serve as referents, but her work "makes up" the Mirabal sisters rather than brings them from the pages of history: "So what you'll find here are the Mirabals of my creation, made up but, I hope, true to the spirit of the real Mirabals. In addition, though I had researched the facts of the regime, and events pertaining to Trujillo's 
thirty-one-year despotism, I sometimes took liberties—by changing dates, by reconstructing events or incidents" (324). She states that the mission of her book lies in the sisters' humanization rather than simply imitating history books, which reproduce facts and pieces of information (324). Álvarez's position reflects Hayden White's, for whom a historian should use the past not as an end in itself, but as a means of providing new perspectives (21). Álvarez proposes to give a more human view of the Mirabal sisters. She expresses that fiction overcomes history by reproducing a historical environment that can be better understood through imagination: "For I wanted to immerse my readers in an epoch in the life of the Dominican Republic that I believe can only finally be understood by fiction, only finally redeemed by imagination" (324). Linda Hutcheon notes this attitude in many fictions that apply historical texts as referents and shows that they help in the human understanding and impose a certain order to chaotic events or to chaos itself: "But many theorists [White, Jameson, Mink, and Martin] today have pointed to narrative as the one concern that envelops all of these, for the process of narrativization, of imposition of meaning and formal coherence on the chaos of events. The conventions of narrative in both historiography and novels, then, are not constraints, but enabling conditions of possibility of sense-making" (11). The attitude of the novel towards history recalls Hayden White's position in "The Burden of History," a chapter of The Tropics of Discourse: Essays in Cultural Criticism, who urges his friends to interpret the past not as an end, but as a means to understand the present: "The contemporary historian has to establish the value of the study of the past, not as an end in itself, but as a way of providing perspectives on the present that contribute to the solution of problems peculiar to our own time" (41). He states that historians should cease to assert supremacy and attachment to the truth of historical texts and dedicate themselves to establishing connections between the past and the present. Historical texts should constantly question themselves in order to better understand what happened.

The historians, whose texts serve as a basis for the revision of history attempted by Álvarez, present the incident of the Mirabal sisters 
assassinated under Trujillo's orders as an important episode in Dominican history. She states that Trujillo had reduced the list of his opponents to two, the Catholic Church and the Mirabal sisters, and then describes the sisters and their relationship with Trujillo. Trujillo's order was carried out, and the three sisters were killed in an ambush together with Rufino de la Cruz, the chauffeur who drove them back home from Puerto Plata where they had gone to visit their husbands, who were incarcerated and accused of participating in subversive acts against the government. The official version of the event offered by Trujillo's government explains that they died in an accident (Diederich 71). However, the non-official version, and closer to the actual facts, exposes Trujillo's evil hand as the main moving force behind the murders (not death by accident) of the three sisters. Trujillo could not cover his role in this crime and eventually the assassination of the Mirabals hastened the downfall of the dictator because his opponents began to conspire against him due to the fact that they could not understand or accept that Trujillo had reached the point of killing three innocent women.

Álvarez revises these official stories to separate truth from myth regarding the three sisters. Minerva, who dominates the narrative space appears as a character who wishes to change the established order because she dislikes and refuses to tolerate the rules, laws, and regulations set by the patriarchal system that prevails in her house, her school, and the government. The first episode about her conduct and attitude presents her setting free a female rabbit, after opening the cage that kept it imprisoned (11). In future episodes we read how she clashes with her father because he lives in adultery, has a mistress and has fathered children outside his marriage. She slaps Trujillo and rejects him when he attempted to seduce her. After the incident with Trujillo, they force her to apologize, but she does it improperly, unwillingly, and without subjugating: "It is just sort of an apology. All I will give" (109). Minerva stand up to members of the secret police who tortured her and tried to scare her into confessing about her role in the clandestine operations to remove Trujillo from power $(92,100)$. 
The narrator, through the filter of Dedé back in 1960, portrays her as the respected and beloved heroine: "The rumors were everywhere. Trujillo wanted her killed. She [Minerva] was becoming too dangerous, the secret heroine of the whole nation" (198). The narrator employs María Teresa's voice not so the reader can become acquainted with her as a character, but to present Minerva to the audience. María Teresa's personal diary, which the narrator allows to read, displays essential information that aids the reader learn about Minerva's character. We learn from her rebellion, her love for Manolo, her participation in clandestine activities, and her experience in jail. María Teresa's narration presents her as a heroine who suffers for fighting against the regime, and as a character whose exemplary life serves as a model for living under the Catholic Church doctrine. Minerva fights for God, country, family, and high moral values. During her adolescence, she promises God to give up swimming (an activity that she greatly enjoys) for a year, in exchange for divine help to enter law school and subsequently practice the profession of her dreams, law (35). Later, in "La 40," a prison overseen by Trujillo, Minerva, María Teresa and other political prisoners share the space with common criminals. Minerva persuades all political prisoners to use crucifixes as an emblem of their subversion. When confronted by the prison authorities, she suffers the punishment of living "on her own" for three weeks rather than giving up her crucifix, as requested by guards during a general inspection (237).

The narrator allows Minerva to tell her story using the first person, which vests her with more credibility. Strategically, the narrator allows her voice to close the novel; she narrates the final scene that occurs right before the Mirabal sisters march to their death (297). Her narrative in this final part of the third section provides us with the sisters' perspective in crucial moments before the novel ends. It gives us a more human and direct version of what in the past was exclusively told in third person and closes the historical gap between what history books explained took place and what a first hand witness (albeit fictitious) narrates as the actual version of events. Minerva, Patria, and María Teresa's tragedy becomes more credible and, therefore, more powerful to the reader. 
Although Trujillo lacks considerable narrative space and Minerva presents him as a typical villain and antagonist. He dwells in the novel as a ghost whose presence not everyone can necessarily see, but they can all feel. Foucault has stated that, in a society, power has similar features: "Power is everywhere; not because it embraces everything, but because it comes from everywhere" (History 93). In the novel, we perceive not so much Trujillo himself who rarely appears in the text, but rather Trujillo's power. His character evolves and grows old throughout the novel, but the omnipotence of his power never wanes. In her diary, María Teresa refers to the similarity between the power of Trujillo's government and that of God, omniscient, and omnipresent. One cannot escape the power of his dictatorship and his wide governmental network, represented by the icon of the president's picture and his vigilant look: "I see the picture of our president with eyes that follow me around the room, and am thinking he's trying to catch me doing something wrong. Before, I always thought our president was like God, watching over everything I did" (39). Howard J. Wiarda explains that the methods of control of Trujillo's dictatorship included indoctrination, brainwashing, torture, and murder:

When indoctrination and brainwashing failed, the dictatorship resorted to relentless physical torture. Those who survived were so ruined, physically and mentally, that Trujillo had little to fear from their release. Some were disposed of by being "shot while attempting to escape," while another was reported to have "hung himself in his cell (56)."

Sinita, a secondary character, explains that her uncles and father had collaborated with Trujillo's regime, but they had turned against him because they did not agree with the inhumane methods of governing and controlling. In reprisal Trujillo's lackeys tortured them, one by one, in a similar way to what Wiarda mentions. Eventually, Sinita's relatives and father lost their lives. Sinita had herself experienced the power of Trujillo's dictatorship when members of his 
control and power network had killed her brother José Luis in front of her when they were buying a lottery number. "José Luis asked for a lucky number. When the dwarf went to hand him the ticket, something silver flashed in his hand. That is all Sinita saw. Then José Luis was screaming horribly .... Sinita looked over at her brother, and the front of his white shirt was covered with blood" (19). Sinita's intervention stands out as a representative story of all the accounts of abuse in Trujillo's dictatorship. And, even though the novel depicts Trujillo and his power network as cruel assassins and abusers of power, the final thesis she proposes argues that we humans constitute evil beings by nature and we kill each other even without the necessity of dictators or secret police: "... as if to prove we could kill each other even without a dictator to tell us to" (211). One cannot find the point of origin of power because, as Foucault expressed, it comes from everywhere, he gets his power from everywhere. These centers govern through implicit laws that everyone obeys and that Foucault calls exclusion laws, the same that have subdivisions among which prohibition laws stand out. Foucalt argues that there are three rules of prohibition: "We have three rules of prohibition, covering objects, ritual with its surrounding circumstances, the privileged or exclusive right to speak of a particular subject" (The Archaeology 211). Foucault states that the members of a society obey these rules because a power, whose center we cannot pinpoint but that exists. Enacts them and enforces their obedience. All of us know of what these rules consist and all of us violate them (The Archaeology 211). The novel masterfully reproduced the rules of prohibition of Trujillo's government through the censorship or self-censorship of María Teresa's diary. María Teresa writes about Minerva's clandestine activities, but she must bury the journal because the content could compromise her sister and members of the subversive group (The Archaeology 211). With her first diary, this operates simply as a narrative strategy to demonstrate that one must be cautious of the governing omnipotent power, because we readers have access to what she writes (43). With the diary that she keeps when in jail something different happens. She starts to write since the $55^{\text {th }}$ day of enclosure, but in this case, we do not have access to María Teresa's 
complete narrative, since a censor, of unknown identity, has ripped out certain pages. We assume that they provide information forbidden by the rules of prohibition and the censor tried to protect fellow members of the subversive movement or/and family. Instead of the narrator's text, there appear statements similar to the following: "[Pages torn out]" (234, 241-3). And in the final pages of the diary, words have been crossed out in order not to be read: "When the door opened, and was brought in." (244-55).

María Teresa adheres to the rules of prohibition and acts with caution in what she does and says, and the way she leads her life. Note that we have access to her thoughts through a means whose first innate characteristic make it a private document. She expresses herself, not to make her voice heard, but to speak out without interfering in other people's business. She respects and would like to be like Minerva, but she finds herself too conscious about lacking the personal characteristics that her sister has inherited. In no way, the novel presents her as a weak character because she has an inner strength and the main narrative voice depicts her as Minerva alter ego or complement, whom she always follows. In prison, Minerva and María Teresa give each other moral support and we notice that María Teresa's restraint complements Minerva's bravery and determination.

Patria represents the sister who most accepts the rules of prohibition and fits better within the established order. Therefore, her occasional uprising and violation of society's laws stands out as one of the most memorable scenes of the novel. She defines her life using the parable of the two foundations, in which a man wisely builds his house over a rock and the exterior powers cannot destroy it (Matthew 7:24-29). Her life has been founded over similar foundations and for eighteen years she has stood and triumphed over external threats (148). Nevertheless, Patria moves away from this safety by experiencing events that make her change and review her way of thinking. She loses her life as it was and replaces it with one more similar to her sisters': "All at once, I lost my home, my husband, my son, my peace of mind. But after a couple of weeks living at Mama's, I got used to the sorrows heaped upon my 
heart" (200). She conserves her passionate religious fidelity as observed in her accounts, but she represents the sister who most evolves as a character because the Patria who dies on the road together with Minerva and María Teresa differs completely from the one we first met.

This presentation of the main characters has to be reconstructed from the fragmenting information that the foreign narrator/researcher reads and researches in order to recreate events as though she tried to solve a jigsaw puzzle. The hypodiegetic narrator, who ultimately organizes the material, uses the four sisters' narrative voices, but never offers four perspectives of the same material, subject, event, or character because instead of repeating, they complement one another and each of the one tells a piece of information that the other narrative voice has not communicated already. For instance, María Teresa and Minerva are incarcerated under Trujillo's order. We get to know about the arrest and life in the Mirabal house from January to March, 1960, through Patria's narrative (200-26). In March, 1960, María Teresa takes control of the narrative voice through her diary and tells us what happened until August of the same year, but from the incarcerated sisters' perspective. So, we have two views, one of those who suffer in enclosure, and one of those who suffer outside because their beloved ones remain in prison (227-56). The novel gives the information of what happens to the Mirabals from January to August 1960, but it divides it into two parts. Two narrative voices tell it, speaking from two different backgrounds. María Teresa's version from January to March or Patria's from March to August is unknown. However, between the two of them, they provide the reader with a chronological version of the facts.

The novel uses a similar strategy to narrate the moments before the sisters' assassination presented in the section "Epilogue." In the text, the author incorporates multiple versions of possible ways in which the massacre could have happened. She recognizes the impossibility of providing an absolute and truthful version and instead presents several different versions. In the Time of the Butterflies adds a selfreferential comment regarding the process of going from fiction to reality or from reality to fiction: "There were several versions" (302). 
The text collects these versions and delivers them to the reader in Minerva's account of the moments that preceded her murdering. Her words answer the how, who, when, where, and why they were killed, as in a detective novel. Her statement includes within the voice of peasants, hearing witnessing of the event, official versions, accounts of those who last saw them alive, and several others. However, in each case the reader should ask him/herself not about what information is provided, but from where it proceeds. One knows the time at which they die because a peasant who had heard the noise of the car falling down the hill at the moment the radio gave the time: "It was seventhirty. The way I know is one of my visitors, Mateo Núñez, had just begun listening to the Sacred Rosary on his little radio when he heard the terrible crash" (303). The peasant's words seem credible, but the reader must remember the neighbors' attempt and strife to mythicize the Mirabal sisters. In another line, of which the veracity can be questioned for obvious reasons, Dedé states that her sisters were not raped by their terminators because she had contact with them when she dressed them in the mortuary (307). Also one can question other witnesses' accounts which state that they were warned not to pass by the place where the sisters were killed because they were waiting for them, but Minerva did not care about the warning (291).

The narrator/researcher has a characteristic that prevents her from becoming an impartial filter that simply shows us what happened in order for us to have a complete view of the sisters. She tries to understand the multiple existing versions of the facts and presents the Mirabal sisters as well developed, complete characters/people accessible to an audience not used to coping with these themes: dictatorships, human rights violation, unpunished assassinations, and abuse of power. The narrator/researcher could be easily associated with Álvarez for the references to a "gringa dominicana" who speaks a "Spanish no so good" and who does not know the world that once was hers, but that an extended leave has forced her to forget it or at least has led her not to act by the standards and rules of the culture (3). She calls to meet with Dedé and strives in order to arrive on time. Both facts 
suggest that she knows little about the culture that lacks the American obsession for punctuality:

"About what time?" the voice wants to know.

Oh, yes, the gringos need a time. 'Any time after three or three-thirty, four-ish.'

'Dominican time, eh?' The woman laughs.

"Exactamente!" Finally, the woman is getting the hang of how things are done here (4).

A similar experience happens between the two of them during the exchange to find out the place's address. Dedé, instead of providing an exact address, offers similar instructions which are known to the people who live there, but are strange to the outsider who comes from a different, far, and alien world, where the streets have names and numbers: "It is just down the road by the anacahuita tree. We don't name them. You see most of the campesinos around here can't read, so it wouldn't do us any good to put names on the road" (3).

This position of being born Dominican, but acculturated as an American allows her to observe and present the text from a unique view and perspective. She travels to the places of the facts to research the sisters' story and to get to know the archive that includes not only the official versions, but also the most credible mythicized oral accounts provided by Dedé, the Mirabals' other relatives, neighbors and the like. The narrator/researcher uses the focus of a foreigner who interprets and explains the events to her specific audience, the readers of the place where she now lives: "I hope this book deepens North Americans' understanding of the nightmare you [The Dominican People] and the heavy losses you suffered" (47). She makes accessible the place, the culture, and the story she tries to tell readers who do not know the life in the Dominican Republic and who use the narrator's presentation to be able to understand the life in this world of which they are unaware. She serves as a filter to readers who are unaware of 
and far from these events because they read about facts that, according to their understanding, would never happen in their surroundings.

Dedé ends the novel expressing her emotional situation of living damned to remember them as she has been doing for more than thirty years, between 1960 and 1994 (313). Rightly so, the novel does not reach its climax with the dead of the Mirabal sisters, but presents them alive when they were children and lived with their parents (321). After all, Dedé has inherited the mission, not the punishment, of keeping them alive and conserving the spirit of the beautiful Mirabal sisters, who gave their lives by opposing the dictatorship. This happy ending reminds us that the proposed audience of the novel likes happy endings. Dedé survives to tell the story. And the novel stands as proof of her purpose. The text masterfully creates the impression that we receive the story from the voices of the four Mirabal sisters. However, when examining the narrative strategies, we should consider that the four sisters do not provide the stories, but Dedé, and that we read everything through her focusing filter because she has accumulated story after story, which has contributed to the myth of the sisters. In the Time of the Butterflies starts from Dedé's version and because of its nature, becomes an interpretation and fictionalization of Álvarez, who reinvents and recreates it. The Mirabal sisters remain as examples of ordinary, but exceptional women who fought for a common good, just how Dedé remembers them: "And I see them all in my memory" (321). And ironically for Trujillo, his death eternalized them in the minds of those who now mythicize and adore them as saints. The novel looks closely at history and myth in order to give a more "real" view through Álvarez's fiction and imagination, but eventually In the Time of the Butterflies contributes to the perception of characters as myths. The Mirabal sisters have reached dimensions that result impossible to simply fit into the huge labels of "real" and "true." In the Mirabal sisters story, the interwoven of myth and history, objectivity and subjectivity, and reality and imagination have erased or relocated the limits which traditionally separate them. 


\section{References}

Álvarez, Julia. Before We Were Free. New York: Knopf Book for Young Readers, 2002. . A Cafecito Story. White River Junction: Chelsea Green Publishers, 2001.

. En el tiempo de las mariposas. Trad. Costa Picazo. New York: Dutton/ Plume, 1995.

. Finding miracles. New York: Knopf Book for Young Readers, 2004.

. A Gift of Gracias: The Legend of Altagracia. New York: Knopf Book for Young Readers, October 2005.

_. How the Garcia Girls Lost Their Accents! New York: Penguin, 1991.

. How Tía Lola Came to Visit Stay. New York: Knopf Book for Young Readers, 2001.

. In the Name of Salome. Chapel Hill: Algonquin, 2000.

. $n$ the Time of the Butterflies. Chapel Hill: Algonquin, 1994.

. Saving the World. Chapel Hill: Algonquin Books, April 2006.

. The Secret Footprints. New York: Knopf, 2000.

. Yo! New York: Penguin, 1997.

. Web Site. 10 July 2007. <http://www.juliaalvarez.com>.

Bing, Jonathan. Interview. "Julia Álvarez: Books That Cross Borders." PublishersWeekly 16 dec 1996: 38-39.

Diederich, Bernard. Trujillo: The Death of the Goat. Boston \& Toronto: Little, Brown and Co., 1978.

Foucault, Michel. The Archaeology of Knowledge. 1969. Trans. Alan M. Sheridan. New York: Pantheon, 1972. 
. "The Discourse in Language." Trans. Rupert Swyer. Appendix of The Archaeology of Knowledge, Foucault. 215-37.

. History of Sexuality. Trans. Robert Hurley. New York: Vintage, 1980.

Gónzalez Echevarría, Roberto. Myth and Archive: A Theory of Latin American Narrative. Cambridge Studies in Latin American and Iberian Literature 3. Cambridge: Cambridge University Press, 1990.

Hutcheon, Linda. A Poetics of Postmodernism: History, Theory and Fiction. New York \& London: Routledge, 1988.

Morales, -Ed. Interview. "Madam Butterfly: How Julia Alvarez Found Her Accent." Village-Voice-Literary-Supplement. Nov 1994: 13.

Santa Biblia. Ed. Casiodoro de Reina. Rev. Cipriano de Valera. Nashville, Camden \& New York: Thomas Nelso, 1960.

White Hayden. Tropics of Discourse: Essays in Cultural Criticism. Baltimore \& London: John Hopkins University Press, 1978.

Wiarda, Howard. Dictatorship and Development: The Methods of Control in Trujillo's Dominican Republic. Gainesville: University of Florida Press, 1968. 